\title{
CAPTAÇÃO VEDADA DE SUFRÁGIO
}

\author{
JEAN FERNANDES BARBOSA DE CASTRO
}




\title{
CAPTAÇÃO VEDADA DE SUFRÁGIO
}

Recebimento: 02/09/2013

Aceite: 01/11/2013

Jean Fernandes Barbosa de Castro ${ }^{1}$

\section{RESUMO}

O presente trabalho científico versa sobre o estudo da captação vedada de sufrágio à luz dos princípios democráticos. No plano de construção do tema, haverá uma tentativa de compilação dos conceitos fundamentais que envolvem a dogmática jurídica do Direito Eleitoral, em harmonia com o manto do Tecido Constitucional, de modo a facilitar a compreensão da abordagem central. No campo sistemático, procurar-se-á delinear uma análise teórico-pragmática do instituto, com emanação de entendimentos do Colendo Tribunal Superior Eleitoral. O trabalho despretensioso foi edificado a partir de pesquisas doutrinárias e jurisprudenciais, encontrando suporte embrionário no Direito Eleitoral.

Palavras-Chave: Princípios Fundamentais de Direito Eleitoral. Sufrágio Universal. Elegibilidade. Captação Vedada de Sufrágio. Natureza Jurídica. Elementos Estruturantes. Ação por Captação Vedada de Sufrágio.

\begin{abstract}
The present work deals with the scientific study of fenced suffrage capture the light of democratic principles. On the construction plan of the theme, there will be an attempt to build the fundamental concepts that involve the legal Electoral law Dogmatics, in harmony with the

1 Juiz de Direito do Estado de Tocantins, titular da Comarca de Aurora do Tocantins-TO. Foi advogado, delegado de Polícia no Distrito Federal. Exerceu a Docência nas Faculdades IESGO, em Formosa-GO, onde lecionou as disciplinas de Direito Penal, Processual Penal, Direito Empresarial, Direito Civil e Processual Civil. E-mail: jeandecastro@tjto.jus.br.
\end{abstract}


cloak of Constitutional Tissue, in order to facilitate the understanding of the central approach. The systematic field, we will seek to outline a theoretical and pragmatic analysis of the Institute, with understandings of the emanation of Colendo Superior Electoral Court. The unpretentious work was built from doctrinal and jurisprudential research, finding embryonic support in electoral law.

Keywords: Fundamental principles of electoral law. Universal Suffrage. Eligibility. Fenced suffrage collection. Legal Nature. Structuring Elements. Action by Obtaining suffrage Sealed.

\section{INTRODUÇÃO}

As eleições federais e presidenciais se avizinham e juntamente com elas várias controvérsias e consequências jurídicas emanam do estudo de institutos jurídicos em torno do Direito Eleitoral. Dado o momento pré-eleitoral, temos que o estudo dos direitos políticos em um quadro ampliativo é oportuno e lapidar.

\subsection{Princípios constitucionais}

Nesse ponto de partida, pensamos que o Direito Eleitoral deve ser visto sob o ângulo dos princípios constitucionais. $\mathrm{E}$ dentro dessa perspectiva de estreita confluência com o filtro axiológico do Texto da Constituição, o Direito Eleitoral se assenta nos Princípios Republicano, Democrático e Federativo, 
conforme ensina Francisco de Assis Vieira Sanseverido².

O Princípio Republicano foi adotado como forma de governo na Ordem Constitucional Vigente, conforme estabelece 0 art. $1^{\circ}$ da Constituição Federal. Advém dessa opção constitucional, a temporariedade dos mandatos políticos, a eletividade e responsabilidade dos governantes eleitos pelo sufrágio universal. No que concerne ao regime político, o Princípio Democrático é consectário lógico da Democracia Representativa, consistente no fato do povo exercer o poder político por intermédio de seus representantes eleitos, art. $1^{\circ}, \S$ único, da CRFB. Por seu turno, o Princípio Federativo se assenta no fundamento constitucional, segundo o qual é formado pela união indissolúvel da União, dos Estados, do Distrito Federal e Municípios, os quais são dotados de autonomias, dentre elas a capacidade de autogoverno, podendo proceder à escolha de seus representantes, art. $1^{\circ} \mathrm{c} / \mathrm{c}$ art. 18 da CRFB.

Fundamental é o papel do princípio do Sufrágio Universal, erigido à categoria constitucional, conforme normatização inspirada no art. 14, caput, da CF. Dispõe o núcleo constitucional, que a soberania popular será exercida pelo sufrágio universal e pelo voto direto e secreto, com valor igual para todos. A Carta Magna elegeu a proteção do voto como núcleo intangível, ex vi do art. 14, caput, c/c art. 60, inciso II, do $\S 4^{\circ}$, ambos da CF. Assim, tal proteção não poderá ser extirpada ou minimizada no contexto normativo.

2 SANSEVERINO, Francisco de Assis Vieira. Direito Eleitoral - P. 21. Editora Verbo Jurídico, 2010. 
Em rica argumentação jurídica, José Jairo Gomes averba que o sufrágio universal:

(...) Na seara jurídica, designa o direito público subjetivo democrático, pelo qual um conjunto de pessoas - o povo - é admitido a participar da vida política da sociedade, escolhendo os governantes ou sendo escolhido para governar e, assim, conduzir o Estado. (.... ${ }^{3}$

Arremata o renomado doutrinador que o sufrágio traduz o direito de votar e ser votado.

Cabe obtemperar que denota-se do princípio em comento, o significado de um direito de participação do povo na escolha de seus representantes, através do exercício do voto, que é a concretização jurídica do sufrágio. Ele se lastreia no postulado da isonomia, com valor igual a todos, e não sofre restrição pela capacidade econômica, cultural ou relativa ao sexo (sufrágio restrito).

A questão principiológica é deveras complexa e não se limita à generalidade Constitucional. Outros autores de Nomeada, como o já citado José Jairo, também destacam outros princípios presentes no Direito Eleitoral, v. g. o Estado Democrático de Direito, o poder soberano, o sufrágio universal, a legitimidade, a moralidade, a probidade e a igualdade, os quais, não obstante a sua relevância, não serão objeto de análise neste escrito, dada a sua pretensão estreita.

De todo o exposto, somos levados a crer que os princípios

3 GOMES, José Jairo. Direito Eleitoral - P. 39. Editora Atlas, 2011. 
examinados dão colorido especial ao Direito Eleitoral, na medida em que norteiam a interpretação jurídica no processo eleitoral.

\subsection{Elegibilidade}

Ainda em sede de considerações iniciais, outro tema merece notícia, pela sua conexidade com o tema proposto neste ensaio.

Vem à tona o estudo breve da Elegibilidade.

A aptidão de votar e ser votado é a representação da capacidade ativa e passiva, respectivamente. Com efeito, a participação popular no processo político remonta algumas condições (status activus de Jellinek). Para isso, cidadão deverá se submeter ao alistamento eleitoral, que se faz mediante a qualificação e inscrição do eleitor $\left(\mathrm{CF}\right.$, art. $14, \S 1^{\mathrm{o}}$, I, II; $\S 2^{\circ}$; CE, art. 42; Lei n ${ }^{\circ} 7444 / 85$; Resolução $n^{\circ} 21.538 / 2003$ do TSE), lembrando que os direitos políticos podem ser privados de forma definitiva (CRFB, art. 15, I e IV) ou temporariamente, através de suspensão (CRFB, art. 15, II, III e V).

Além disso, o cidadão será elegível quando estiver apto a concorrer às eleições, podendo receber votos, o que também exige alguns requisitos.

Cabe sublinhar que as condições de elegibilidade encontram-se plasmadas no art. $14, \S 3^{\circ}$, da Lei Maior, que normatiza:

"` $\$ 3^{\circ}$ - São condições de elegibilidade, na forma da lei: 
I - a nacionalidade brasileira;

II - o pleno exercício dos direitos políticos;

III - o alistamento eleitoral;

IV - o domicílio eleitoral na circunscrição;

V - a filiação partidária;

VI - a idade mínima de:

a) trinta e cinco anos para Presidente e Vice-Presidente da República e Senador;

b) trinta anos para Governador e Vice-Governador de Estado e do Distrito Federal;

c) vinte e um anos para Deputado Federal, Deputado Estadual ou Distrital, Prefeito, Vice-Prefeito e juiz de paz;

d) dezoito anos para Vereador."

Para o festejado constitucionalista José Afonso da Silva, tem elegibilidade,

(...) quem preencha as condições exigidas para concorrer a um mandato eletivo. Consiste, pois, a elegibilidade no direito de postular a designação pelos eleitores a um mandato político o Legislativo ou no Executivo. Numa democracia, a elegibilidade deve tender à universalidade, tanto quanto o direito de alistar-se eleitor. Suas limitações não poderão prejudicar a livre escolha dos eleitores, mas $\mathrm{Sr}$ ditadas apenas por considerações práticas, isentas de qualquer condicionamento político, econômico, social ou cultural. $(\ldots)^{4}$

\section{De se ver que as causas de elegibilidade constituem requisitos essenciais para quem pretende candidatar-se a cargo}

$4 \quad$ SILVA, José Afonso da. Curso de Direito Constitucional Positivo. P. 367. 17ª Ed. São Paulo: Malheiros, 2000. 
político.

A nacionalidade brasileira ressai do vínculo jurídicopolítico que liga um indivíduo a um determinado Estado. A sua comprovação se dá com o alistamento eleitoral. O pleno exercício dos direitos políticos assenta-se na capacidade de votar e ser votado. Já o alistamento eleitoral constitui a mola mestra para a aquisição da cidadania, sendo comprovado pelo título eleitoral. Por seu turno, o domicílio eleitoral deve ser na circunscrição eleitoral em que for domiciliado o candidato, lembrando que tal não se confunde com o domicílio civil e o Colendo TSE tem admitido a comprovação do vínculo com domicílio eleitoral "afetivo" do cidadão (Res. TSE n' 21.538/2003, art. 65). Destaca-se que a filiação partidária é também essencial e representa o vínculo entre o cidadão e a entidade partidária, nos moldes dos artigos 16 a 22 da Lei n 9.096/95, que dispõe acerca dos Partidos Políticos. Assim, vedada a candidatura avulsa, ou seja, do candidato sem partido. Nesta toada, importante o estudo da fidelidade partidária. À derradeira, temos a idade mínima que deverá obedecer aos parâmetros constitucionais agasalhados no art. $14, \S 3^{\circ}$, VI, da $\mathrm{CF}$, sendo certo sublinhar que o requisito da idade mínima deve ser atendido na data da posse, art. $11, \S 2^{\circ}$, da LE (lei das eleições).

À guisa de complemento, a aferição das condições de elegibilidade é requisito essencial para o exercício da capacidade passiva eleitoral, havendo divergência jurisprudencial acerca do momento em que deve o candidato reunir as condições. Uma corrente entende que deve ser na data do registro da candidatura, 
ao passo que a outra defende que tal requisito seja observado na data da eleição.

\subsection{Inelegibilidade}

Passamos ao estudo da inelegibilidade.

As inelegibilidades constituem o lado inverso das elegibilidades. Elas dão a entonação da falta de capacidade eleitoral passiva. Deacordo com a sua natureza, as inelegibilidades podem ser absolutas, ou seja, equivale ao impedimento para concorrer a qualquer cargo político (relacionadas a características pessoais); ou relativas, que constituem restrições em concorrer a determinados cargos, em razão de situações especiais.

A Constituição Federal prevê diversas hipóteses de inelegibilidades no artigo $14, \S \S 4^{\circ}, 6^{\circ}$ e $7^{\circ}$.

Existem também inelegibilidades legais, as quais se circunscrevem, necessariamente, em leis complementares e, ao contrário das absolutas, estão sujeitas à preclusão, caso não alegadas oportunamente.

Hodiernamente, a lei que dispõe sobre as inelegibilidades relativas encontra-se erigida na $\mathrm{LC}^{\circ}$ 64/90, edificada a partir das diretrizes do $\S 9^{\circ}$ do art. 14 da CF, sendo importante ressaltar que a lei sob comentário sofreu alterações com a égide da Lei Complementar $n^{0}$ 135/2010, conhecida como lei da "ficha limpa". 


\section{CAPTAÇÃO VEDADA DE SUFRÁGIO - ART. 41-A DA LEI No 9.504/97}

O tema nevrálgico do nosso estudo é a captação vedada de sufrágio.

Este trabalho busca, desta forma, examinar a infração eleitoral sedimentada no art. 41-A da Lei $\mathrm{n}^{\circ}$ 9.504/97, o qual prescreve:

Ressalvado o disposto no art. 26 e seus incisos, constitui captação de sufrágio, vedada por esta Lei, o candidato doar, oferecer, prometer, ou entregar, ao eleitor, com o fim de obter-lhe o voto, bem ou vantagem pessoal de qualquer natureza, inclusive emprego ou função pública, desde o registro da candidatura até o dia da eleição, inclusive, sob pena de multa de mil a cinqüenta mil UFIR, e cassação do registro ou do diploma, observado o procedimento previsto no art. 22 da lei Complementar no 64 , de 18 de maio de 1990.

$\S 1^{\circ}$ Para a caracterização da conduta ilícita, é desnecessário o pedido explícito de votos, bastando a evidência do dolo, consistente no especial fim de agir.

$\S 2^{\circ}$ As sanções previstas no caput aplicam-se contra quem praticar atos de violência ou grave ameaça a pessoa, com o fim de obter-lhe o voto.

$\S 3^{\circ}$ A representação contra as condutas vedadas no caput poderá ser ajuizada até a data da diplomação.

$\S 4^{\circ} \mathrm{O}$ prazo de recurso contra decisões proferidas com base neste artigo será de 3 (três) dias, a contar da data da publicação do julgamento no Diário Oficial. 
A propósito, captação ilícita de sufrágio faz parte do rol das condutas vedadas aos agentes públicos no período eleitoral - art. 73 da lei $n^{\circ}$ 9.504/97. Essas condutas, segundo SANSEVERINO (obra já citada), constituem infração eleitoral em sentido amplo, de natureza político-administrativa, principalmente para afirmar que não tem natureza criminal.

\subsection{Conceito}

José Jairo doutrina o seguinte conceito objetivo de captação ilícita de sufrágio;

\footnotetext{
"A captação ilícita de sufrágio é modalidade de abuso de poder. O conceito desse, conforme salientado, é uno, conquanto possa plasmar-se a diferentes situações concretas e ensejar efeitos diversos."
}

\subsection{Constitucionalidade}

O instituto da captação ilícita de sufrágio, como cediço, foi incorporado ao ordenamento jurídico por intermédio de lei ordinária. Ele foi instituído pela Lei n ${ }^{\circ}$ 9.840/99, cognominada Lei das Eleições, sofrendo mudança normativa com a égide da Lei $\mathrm{n}^{\mathrm{o}} 12.034 / 2009$. O fato de tal dispositivo ter constituído sanção de cassação do registro ou do diploma do candidato que praticar captação vedada de sufrágio, fez com que vozes da doutrina eleitoral defendessem a inconstitucionalidade da norma. 
A tese que custou prestigiar grande diáspora doutrinária, fez prevalecer a de que não há se falar em inconstitucionalidade, visto que não criada nova espécie de inelegibilidade, senão, uma modalidade de sanção imposta ao candidato por abuso de poder.

Neste ângulo, pronunciaram o colendo $\mathrm{TSE}^{5}$ e o $\mathrm{STF}^{6}$, afirmando a constitucionalidade do art. 41-A.

\subsection{Ação por captação ilícita de sufrágio}

\subsubsection{Acepção Material}

O objeto da ação por captação ilícita de sufrágio é a cassação do registro ou do diploma, a condenação em multa e, por via reflexa e consequencial, a declaração de inelegibilidade do candidato. Para o reconhecimento da conduta adversada, mister o desajuste na conduta do candidato praticada com o fim de obter voto do eleitor (Respe $n^{\circ} 19.2229$ - Cl. 22 - MG), mediante atos abusivos e ilícitos, segundo os quais configuram infrações eleitorais. Tais quais as hipóteses normatizadas no art. 41-A, vêse que reputam-se vedadas as condutas de doação, oferecimento, promessa ou entrega ao eleitor, de bem ou vantagem pessoal de qualquer natureza, inclusive emprego ou função pública.

A propósito, o pedido de favor político em troca de bens ou vantagens pessoal de qualquer natureza, deve ser demonstrado

\footnotetext{
5 REsp - RECURSO ESPECIAL ELEITORAL - ACÓRDÃO 21221; REsp - RECURSO ESPECIAL ELEITORAL - ACÓRDÃO 21248

$6 \quad$ ADI no $3.592-4$, Informativo STF n 447
} 
de forma inequívoca. Entretanto, tal comportamento pode ser levado a efeito diretamente pelo agente, leia-se, candidato, ou por interposta pessoa, desde que demonstrado que concorreu de qualquer modo para a sua prática. Parece-nos, contudo, que caso a conduta não tenha sido praticada pessoalmente pelo candidato, deverá ser cuidadosa a instrução processual, evitando-se compelir o candidato de participar do processo eleitoral, em homenagem ao postulado do in dubio pro candidato.

Sobre o tema, trazemos à colação alguns precedentes da Corte Superior Eleitoral, a respeito da compra de votos:

4 REsp - RECURSO ESPECIAL ELEITORAL ACÓRDÃO 21221; REsp - RECURSO ESPECIAL ELEITORAL - ACÓRDÃO 21248

5 ADI n 3.592-4, Informativo STF no 447.

"Representação. Art. 41-Ada Lei n 9.504/97. Candidato. Deputado estadual. (...). 2. Para a configuração do ilícito previsto no art. 41-A da Lei ${ }^{\circ}$ 9.504/97 não se faz necessário o pedido explícito de votos, bastando que, a partir das circunstâncias do caso concreto, seja possível inferir o especial fim de agir, no que tange à captação do voto. (...). Ac. De 8.10.2009 no RO no 2.373, rel. Min. Arnaldo Versiani."

"[...]5 Eleições 2008. Prefeito. Representação. Captação ilícita de sufrágio. Art. 41-A da lei 9.504/97. Configuração. Conhecimento prévio. Demonstração. Multa pecuniária. Proporcionalidade e razoabilidade. Não provimento. (....) 2. A caracterização da captação ilícita de sufrágio pressupõe a ocorrência simultânea dos seguintes requisitos: a) prática de uma das condutas previstas no art. 41-A da Lei 9.504/97; b) fim específico de obter o voto do eleitor; c) participação ou anuência do 
candidato beneficiário na prática do ato. 3. Na espécie, o TRE/MG reconheceu a captação ilícita com esteio na inequívoca distribuição de material de construção em troca de votos - promovida por cabos eleitorais que trabalharam na campanha - em favor das candidaturas do agravante e de seu respectivo vice. 4 . O forte vínculo político e familiar evidencia de forma plena o liame entre os autores da conduta e os candidatos beneficiários. $\mathrm{Na}$ hipótese dos autos, os responsáveis diretos pela compra de votos são primos do agravante e atuaram como cabos eleitorais - em conjunto com os demais representados - na campanha eleitoral. (....)(Ac. de 1.12.2011 no AgRREspe no 815659, rel. Min. Nancy Andrighi.).

“[...] Captação ilícita de sufrágio. Pedido expresso de voto. [...] 4. A jurisprudência desta Corte, antes mesmo da entrada em vigor da Lei $n^{\circ} 12.034 / 09$, já se havia firmado no sentido de que, para a caracterização de captação ilícita de sufrágio, é desnecessário o pedido explícito de votos, bastando a anuência do candidato e a evidência do especial fim de agir. [...]"

(Ac. de 5.4.2011 no AI n ${ }^{\circ}$ 392027, rel. Min. Marcelo Ribeiro.)

\section{Entendimento contrário ao reconhecimento da conduta} ilícita eleitoral também é fartamente encontrado no sítio do Colendo TSE, in verbis:

“[...]. Representação. Captação ilícita de sufrágio. 1. A exposição de plano de governo e a mera promessa de campanha feita pelo candidato relativamente ao problema de moradia, a ser cumprida após as eleições, não configura a prática de captação ilícita de sufrágio. 2. Não há como se reconhecer a conduta descrita no art. 41-A da Lei $n^{\circ}$ 9.504/97 quando, a despeito do pedido de voto, não ficou comprovado o oferecimento de bem 
ou vantagem pessoal de qualquer natureza. [...]" (Ac. de 30.11.2010 no AgR-AI n 196558, rel. Min. Arnaldo Versiani.).

“[...] II - Para a caracterização da captação de sufrágio e da arrecadação e gasto ilícito de recursos, previstos nos arts. 41-A e 30-A da Lei 9.504/1997, respectivamente, é indispensável, em razão da gravidade das penalidades aplicadas, a presença de provas contundentes dos atos praticados. [...]" (Ac. de 13.4.2010 no AgR-RO n 2.260, rel. Min. Ricardo Lewandowski.).

“[...]. Captação ilícita de sufrágio. Serviços médicos gratuitos. Ausência de provas. I - A caracterização da captação ilícita de sufrágio exige provas robustas de que a conduta tenha sido praticada em troca de votos. [...]" (Ac. de 13.4.2010 no ARCED n ${ }^{\circ}$ 748, rel. Min. Ricardo Lewandowski.)

“[...]. Oferecimento de cestas básicas durante debate entre candidatos a prefeito. Não caracterização de captação ilícita de sufrágio. Desprovimento. I Promessas de campanha dirigidas indistintamente a eleitores sem referência a pedido de voto não constituem captação ilícita de sufrágio, a que alude o art. 41-A da Lei $\mathrm{n}^{\circ}$ 9.504/97. [...]" (Ac. de 8.4.2010 no REspe $\mathrm{n}^{\circ}$ 35.352, rel. Min. Fernando Gonçalves.).

Detida a análise dos precedentes lançados, observa-se que a exegese jurisprudencial tem assentado pelo necessário envolvimento do agente com o ato ilícito eleitoral, seja pessoal ou por interposta pessoa, devendo demonstrar que concorreu de qualquer modo para a conduta infracional, captando, ou tentando captar o voto ilicitamente. Encontra-se sedimentada ainda a jurisprudência, que a prova da mercancia ilícita eleitoral deve ser contundente, específica e endereçada à pessoa individualizada, 
não sendo dado que se volte de forma genérica e abstrata.

Quanto ao tema do bem jurídico tutelado pela norma, cumpre ressaltar que, na lição sempre oportuna de José Jairo Gomes, consiste em salvaguardar a liberdade do eleitor de votar.

$\mathrm{Na}$ perspectiva da potencialidade lesiva de o fato desequilibrar a disputa eleitoral, é remansosa a jurisprudência no sentido de que basta a compra de um único voto para a adequação da conduta, sendo, pois, desnecessária a demonstração de que a infração seria capaz de influenciar no resultado das eleições.

Nesse aspecto:

\begin{abstract}
"[...]. V - Para a configuração do ilícito inscrito no art. 41-A da Lei $n^{\circ} 9.504 / 97$, acrescentado pela Lei $n^{\circ}$ 9.840/99, não é necessária a aferição da potencialidade de o fato desequilibrar a disputa eleitoral. [...]" TSE Respe no 21.264/AP - DJ 11.-6-2004."
\end{abstract}

\title{
2.3.2 Acepção Processual
}

A ação por captação ilícita de sufrágio segue o rito procedimental expresso no artigo 22 da Lei de Inelegibilidades, por determinação do art. 41-A da lei no 9.504/97.

Seu objeto tem por objeto a cassação do registro ou do diploma, a inelegibilidade do requerido, assim como a condenação em multa.

Sob o aspecto da causa de pedir, assevera José Jairo que o fundamento fático reside na concretização de condutas que denotem abuso de poder, cuja específica finalidade é interferir 
na liberdade e na vontade do eleitor na escolha do seu candidato.

Relativamente aos sujeitos da relação processual, têmse pela necessidade de a parte estar representada por advogado, detentor de capacidade postulatória. No pólo passivo, por seu turno, qualquer pessoa, física ou jurídica, pode figurar, mesmo quem não seja candidato (art. 41-A da lei de regência).

Assevere-se que a doutrina tem entendido pelo descabimento da tutela de urgência para fins de cassação do registro e imposição da inelegibilidade, admitindo, entretanto, a possibilidade da antecipação de tutela com o escopo de cassar o diploma, desde que apreciada depois da proclamação dos resultados das eleições.

Cumpre gizar que a ação poderá ser ajuizada no período eleitoral, leia-se, desde o pedido de registro da candidatura, até a diplomação dos eleitos, ex vi do $\S 3^{\circ}$ do art. 41-A da lei das eleições, sendo incabível a desistência, consoante entendimento jurisprudencial da Corte Superior Eleitoral (TSE - Ac. $\mathrm{N}^{\mathrm{o}}$ 25.094).

Finalmente, quanto à tutela recursal, valemo-nos dos ensinamentos sempre oportunos do Professor José Jairo, em sua obra já citada, o qual traz uma breve sistemática recursal que pedimos vênia para alocar no nosso trabalho: a) não cabe agravo de instrumento contra decisões interlocutórias sob a ritualização do art. 22 da lei de inelegibilidades, ressalvada a possibilidade de interposição de mandado de segurança quando cabível (TSE - AREspe $n^{\circ}$ 25.281); b) eleição municipal, julgamento de mérito - é cabível Recurso Eleitoral para o TRE (CE, arts. 265 
e seguintes) ; c) eleições federais e estaduais, decisões de mérito - é cabível Recurso Ordinário para o Tribunal Superior Eleitoral (CF, art. 121, $\S 4^{\circ}$, inciso III; CE, art. 276, inciso II, alínea a); d) eleições presidenciais, decisão de mérito, cabe recurso ao Supremo Tribunal Federal (CF, art. 121, $\S 3^{\circ}$, e art. 102, inciso III).

\section{CONSIDERAÇÕES FINAIS}

Cabe sublinhar que a captação vedada de sufrágio atenta contra a moralidade das eleições, causando desequilíbrio no processo eleitoral, pois influencia na escolha dos candidatos e das ideologias políticas pelo eleitor.

O bem jurídico tutelado na ação de captação ilícita de votos é a higidez da campanha eleitoral, sendo a sua consequência jurídica, conforme restou assentado, a exclusão do pleito eleitoral pela cassação do registro ou do diploma do candidato que praticar o ilícito da captação do voto.

Em suma, há mecanismos jurídicos que tutelam a ocorrência do ilícito eleitoral que, se caracterizado, poderá dar ensejo a diversos sancionamentos, com vistas a garantir a lisura da campanha eleitoral, permitindo ao eleitor a liberdade de escolha de seus candidatos.

Não obstante o exposto, é necessária a contínua evolução legislativa e jurisprudencial, reservando eficientes ferramentas de combate ao abuso de poder político, tal como a edição da lei da Ficha Limpa (Lei Complementar no 135/2010), verdadeiro marco fundamental para a democracia e o combate à corrupção. 


\section{REFERÊNCIAS}

GOMES, José Jairo. Direito Eleitoral. São Paulo: Editora Atlas, 2011.

LENZA, Pedro. Direito Constitucional Esquematizado. São Paulo: Editora Saraiva, 2010.

SANSEVERINO, Francisco de Assis Vieira. Direito Eleitoral. Porto Alegre: Editora Verbo Jurídico, 2010.

. “Uso da máquina pública" nas campanhas eleitorais: as condutas vedadas aos agentes públicos. Porto Alegre/RS: Verbo Jurídico, 2008.

. Compra de votos, à luz dos princípios constitucionais. Porto Alegre/RS: Verbo Jurídico, 2007.

. Captação ilícita de sufrágio. Revista do Ministério Público. Porto Alegre/RS, no 52, 2004, p. 171-193.

SILVA, José Afonso da. Curso de Direito Constitucional Positivo. $17^{\mathrm{a}}$ edição. São Paulo: Malheiros, 2000. 
TRIBUNAL DE JUSTIÇA DO ESTADO DO TOCANTINS 